\title{
IMAGINÁRIO DA MORTE NAS ELEGIAS DE PROPÉRCIO
}

IMAGINARY OF DEATH IN PROPERTIUS' ELEGIES

\author{
Roberto Arruda de Oliveira ${ }^{1}$
}

Resumo: Cíntia manifesta-se, aos olhos do poeta, como fonte de sofrimento, de ciúmes e infelicidade, sentimento que o atormenta incessantemente a ponto de considerá-lo um mal a ser evitado por todos. O poeta sente-se comumente impelido a buscar na morte o único refúgio para sua dor, a libertação do seu sofrimento, pois não encontra em vida correspondência neste amor. Fica-nos evidente o quanto a presença da morte é "necessária" para reafirmação e exaltação dos sentimentos amorosos, única forma de atrair a compaixão da amada.

Palavras-chave: Propércio; elegia; Cíntia; literatura latina.

Abstract: Cynthia shows herself, in the poet's eyes, as a source of suffering, jealousy and unhappiness, feeling that annoys on and on to the point of considering it an evil to be avoided by all. The poet feels commonly driven to see in death the unique refugee to his pain, the unique liberation of this suffering, for there is no one in life who could match him in love. It becomes clear how the presence of death is "necessary" to reaffirm and exalt loving feelings, only way to attract the sympathy of the beloved one.

Keywords: Properce; elegy; Cynthia; latin literature.

O tema principal das elegias propercianas é o amor por Cíntia, em função do qual o poeta vive em estado de constante vulnerabilidade. Não há, em sua poesia, uma continuidade de eventos como ocorre num romance, e o que percebemos são apenas instantes desta "aventura" que teria perdurado por cinco anos, nos quais os momentos de alegria se alternam com os de tristeza. Vítima desta instabilidade emocional, o poeta manifesta, nos poemas direcionados a Cíntia, uma oscilação em sua vida amorosa chegando até mesmo a sentimentos paradoxais.

Este amor, focalizado sob vários ângulos diferentes, possui características extremamente complexas, apresenta-se muitas vezes como fonte de

1 Doutor em Letras Clássicas pela UFRJ. Professor de Língua Latina, Literatura Latina e Filologia Românica na UFC. 
sofrimento, de ciúmes e infelicidade, sentimento que o atormenta incessantemente a ponto de considerá-lo um mal a ser evitado por todos. A força desse amor se manifesta como uma espécie de doença contra a qual os medicamentos e a magia são ineficazes e emerge como tema principal de sua poética.

Nas mais representativas elegias direcionadas a Cíntia em que Eros se confunde com Thánatos, fica-nos evidente o quanto a presença da morte é "necessária" para reafirmação e exaltação dos sentimentos amorosos. Eis que em Propércio esta mesma tensão se estabelece também como um rito de passagem. O poeta anseia por liberdade: a todo o momento a Morte se configura como uma passagem para um outro plano, para a libertação de suas inquietações amorosas. Desprezado por Cíntia, o poeta se sente comumente impelido a buscar na morte o único refúgio para sua dor, a libertação do seu sofrimento, pois não encontra em vida correspondência neste amor. Seus versos tanatófilos se apresentam como única possibilidade de reafirmação do amor, única forma de atrair a compaixão da amada, de conseguir despertar nela o sentimento que lhe fora negado em vida,

A morte, bem antes dos elegíacos latinos, já havia sido também motivo da poesia gnômica de Mimnermo, na qual aparecia como tema de meditação moral: A velhice chegará, dizia ele, e, mais tarde, Horácio, e com ela a morte, aproveitemos, portanto, a vida ${ }^{2}$. Ao contrário deste sentimento de exaltação à vida, propagava-se no final da República romana uma intensa fobia suscitada pelas guerras civis. O povo, devido à coragem que lhe era exigida, nutria um temor constante pela morte ${ }^{3}$. Esta angústia termina por se projetar na literatura e no pensamento filosófico, sobretudo no epicurista, que se insurge como um remédio contra este mal. De forma alguma, encontraremos esta angústia permanente em Plauto, nem tampouco em Ênio, no qual a morte do inimigo era motivo de alegria e, a do cidadão, de glória. As transformações políticas e filosóficas provocam uma mudança em relação aos valores estabelecidos pela sociedade, fator que, de certo modo, reflete-se na produção poética de natureza subjetiva em que os elegíacos latinos abordam em essência a pulsão do amor face à morte.

Na poesia de Propércio, fica-nos evidente a presença marcante pela morte, cuja articulação se processa, em vários poemas, quer de forma real quer imaginária, servindo de contraponto para a criação de uma dimensão

2 Cf. Mim.,El.,2 D; Hor., Od.,I,IV.

3 Cícero (Les Belles Lettres, 1970, I,91) em suas Tusculanae Disputationes foi testemunha dessa tensão que havia entre o medo e a morte: "Assim ao sábio não embaraça a morte, a qual, por conta de infelizes incidentes, ameaça-nos diariamente, por conta da brevidade da vida, não pode nunca estar muito afastada..." // Itaque non deterret sapientem mors, quae propter incertos casus cotidie imminet, propter breuitatem uitae numquam potest longe abesse... 
dinamizadora em que real e imaginário interagem propiciando assim, condição para que o poeta possa concretizar suas aspirações amorosas. $\mathrm{O}$ desprezo de Cíntia, ao que parece, leva o poeta a nutrir em seu imaginário pensamentos de morte nos quais a visualiza quer lamentando profundamente sua perda, quer zelando por seu túmulo com perfumes e guirlandas. Deseja morrer, pois não encontra em vida correspondência neste amor, e, por isso, invoca constantemente a morte na certeza de que somente assim Cíntia estará ao seu lado. O poeta, por vezes, transmite-nos uma ideia generalizada da morte como vemos nos seguintes versos de caráter quase gnômico:

Nec forma aeternum aut cuiquam est fortuna perennis; longius aut propius mors sua quemque manet. (II,28,57-58)

Nem a beleza é um bem eterno, e ninguém tem uma sorte perpétua; mais cedo ou mais tarde a cada um está reservada a sua morte.

Outras vezes nos lembra, tal qual Horácio, que não devemos procurar saber do dia de nossa morte nem a forma como virá:

At uos incertam, mortales, funeris horam quaeritis, et qua sit mors aditura uia.

E vós, ó mortais, perguntais pela incerta hora das exéquias, $\mathrm{e}$ por que caminho há de chegar a morte.

Esta invocação assume também um caráter até certo ponto fatalista na medida em que a morte surge como um inevitável ciclo ao qual todos estamos sujeitos:

Sed tamen hoc omnes, huc primus et ultimus ordo: est mala, sed cunctis ista terenda uia est.

Mas isto, contudo, é comum a todos, para lá irá a primeira fileira e a última: é doloroso, mas este caminho deverá ser percorrido por todos.

Em outros versos também, de cunho epicurista, percebemos ser a morte algo que o atormentava constantemente, uma verdadeira obsessão até Organon, Porto Alegre, v. 31, n. 60, p. 229-249, jan/jun. 2016. 
mesmo num poema de alegria, de amor, mostra a todos a inexorabilidade dos fados, aos quais tem plena consciência de estar sujeito:

sic nobis, qui nunc magnum speramus amantes, forsitan includet crastina fata dies.

assim a nós, que agora amantes nutrimos um grande sentimento, talvez o dia de amanhã encerre os fados.

Fruto do desprezo e do ciúme, a imagem da morte vem muitas vezes à mente do poeta como um bálsamo, como solução final. Em alguns de seus versos, nota-se, por vezes, um teor epicurista em relação a esse trágico sentimento que lembra a necessidade de aproveitar o tempo que passa, pois o dia da morte é iminente:

Quare, dum licet, inter nos laetemur amantes: non satis est ullo tempore longus amor.

Enquanto nos for permitido, portanto, alegremo-nos, amantes, entre nós: o amor não é bastante longo em tempo algum.

Talvez esta obsessão se devesse a sua experiência pessoal com a morte: presenciou ainda criança a morte de seu pai e até teve de colher as cinzas dele numa urna a qual seria posta no túmulo da família:

Ossaque legisti non illa aetate legenda

patris et in tenuis cogeris ipse lares.

E colheste as cinzas de teu pai que ainda não deveriam ser colhidas naquela idade ${ }^{4} \mathrm{e}$ és obrigado a viver numa humilde casa.

Num só dístico ele nos fala da morte do pai e do confisco de terras do qual sua família fora vítima. Tendo crescido em Assis, nas imediações de Perúsia, com certeza presenciou o cerco daquela cidade etrusca e o terror da repressão política. Em sua última elegia do Monobiblos, dedicada a Tulo,

4 Ele era ainda uma criança "com menos de seis anos fixados juridicamente para a aprovação" // al di sotto dei sei anni giuridicamente fissati per la definizione (Scarcia, p.396) - cf.: ainda Ov.,Her.,XV,61-62: "meus seis anos de idade ainda estavam chegando, quando as colhidas cinzas de meu pai sorveram, prematuramente, minhas lágrimas" // sex mihi natales ierant, cum lecta parentis / ante diem lacrimas ossa bibere meas. 
relembra entristecido o massacre de Perúsia e o horror da Guerra Civil, e dedica a antepenúltima a Galo, um seu parente, o qual, tendo escapado do cerco de Perúsia, foi morto por salteadores. Esta situação caótica acha-se referenciada no que diz o poeta úmbrio, na elegia 17 do livro I, a respeito de uma possível morte iminente: no mar, numa viagem para a Grécia, um temporal põe em perigo sua embarcação, e não sabe ao certo se escapará:

Nec mihi Cassiope solito uisura carinam omniaque ingrato litore uota cadunt.

E Cassiopéia ${ }^{5}$ não há de ver, como de costume, minha embarcação, e meus votos terminam nesta ingrata costa.

$\mathrm{Na}$ elegia 15 do livro I, Cíntia parece planejar uma nova viagem, o que fará do poeta um homem traído. O poeta censura seus perjúrios, sua perfídia, e lembra que ela pode ser vítima da mesma morte iminente aludida na elegia 17 do livro I:

audax a! nimium, nostro dolitura periclo, si quid forte tibi durius inciderit!

Ah! demasiado audaciosa! Hás de padecer de meu perigo, se por ventura a ti algo mais cruel te acontecer!

Mostra a Cíntia o exemplo de lealdade das heroínas míticas, as quais sofriam, pois que seus amantes se encontravam no mar, e lamenta que sua amada não as tenha como exemplo:

At non sic Ithaci digressu mota Calypso

desertis olim fleuerat aequoribus:

multos illa dies incomptis maesta capillis

sederat, iniusto multa locuta salo,

et, quamuis numquam post haec uisura, dolebat

illa tamen, longae conscia laetitiae;

nec sic Aesoniden rapientibus anxia uentibus

Hypsipyle uacuo constitit in thalamo:

Hypsipyle nullos post illos sensit amores,

ut semel Haemonio tabuit hospitio.

$(\mathrm{I}, 15,9-14 ; 17-20)$

5 Esposa de Cefeu e mãe de Andrômeda. Júpiter a colocou entre as estrelas (constelação de Cassiopéia). 
Mas outrora não havia chorado assim Calipso $^{6}$, comovida pela partida do Îtaco ${ }^{7}$, nas solitárias ondas: entristecida, ficara sentada, durante muitos dias, com os cabelos em desalinho,dizendo muitas palavras ao mar injusto. E, ainda que ela nunca mais houvesse de vê-lo depois disso, ela contudo lamentava, consciente da prolongada felicidade. E Hipsípila ${ }^{8}$ não ficou tão ansiosa no leito vazio por causa dos ventos que arrebataram o filho de Éson': Hipsípila não conheceu depois amor algum, uma vez que se consumiu pelo hóspede emônio ${ }^{10}$.

Enquanto Propércio vê, usualmente, a morte como uma libertação, Tibulo, em vários momentos, pensa na morte como algo tenebroso que o impede de ver a amada, como se verifica nesta súplica ao rejeitar a morte:

Abstineas auidas, Mors, modo, nigra, manus; abstineas, Mors atra, precor.

Afasta agora, negra Morte, as mãos ávidas;afasta-as, ó Morte tenebrosa, suplico-te.

É o lamento de ter vivido que encontramos em Propércio, pois a vida sem a amada é visualizada como a própria morte. O poeta, muitas vezes, deseja a si um curto tempo de vida: talvez até lhe tivesse sido melhor ter morrido ainda criança. Muitos dissabores podem nos advir em vida: por que nutrir esperanças por uma vida muito longa? Mais vale, muitas vezes, morrer precocemente, pois assim estaremos livres de possíveis surpresas nefastas:

Atque utinam primis animam me ponere cunis iussisset quaeuis de Tribus una Soror! nam quo tam dubiae seruetur spiritus horae?

6 Calipso reinava na ilha Ogígia na qual Ulisses aportou. Apaixonou-se pelo herói e lhe prometeu a imortalidade se se casasse com ela. Mas Ulisses preferiu regressar a sua pátria, para os braços de sua fiel esposa Penélope.

7 Ulisses.

8 Era filha de Toas, rei de Lemnos. Conta a lenda que como as mulheres de Lemnos não prestavam culto a Vênus, a deusa as castigou com um fedor tão intenso que seus maridos as abandonaram. Estas, então, mataram seus pais e esposos. Hipsípila perdoou seu pai e o salvou o que lhe garantiu o reinado deste lugar destituído de homens. Quando a embarcação dos argonautas chegou em Lemnos, Hipsípila se apaixonou por Jasão de quem teve dois filhos. Jasão a abandonou dois anos depois.

9 Jasão.

10 Pelo termo "emônio" pode-se designar poeticamente toda a região setentrional da Grécia. 
E oxalá qualquer uma das Três Irmãs tivesse me ordenado deixar a vida no berço;pois, para que o sopro de vida deve ser preservado a tão incerta hora?

Seu grau de insatisfação com a falta de reciprocidade de Cíntia pode ser atestado com o emprego no poema acima do verbo iussisset, através do potencial irreal, na manifestação de seu desejo de ter morrido na infância e não ter conhecido assim a amargura deste amor. As Parcas, deixando-o viver até então, permitiram-lhe suportar indeterminadamente este sofrimento.

A obsessão pela morte é percebida em seu conflito amoroso com Cíntia, manifestando-se, por vezes, como uma solução final diante de uma separação iminente. No mar, numa viagem à Grécia $(I, 17)$, Propércio se arrepende de haver fugido de sua amada. O poeta, então, visualiza-se na iminência de ser castigado por um temporal que põe sua nau em perigo. Maldiz aquele que descobriu os caminhos do mar e a navegação, e teme encontrar a morte longe de Roma. Se morrer ali, Cíntia poder-lhe-á fazer as devidas oferendas diante de sua tumba. Ao contrário da vida, sujeita às vicissitudes emotivas, a morte parece lhe assegurar a fidelidade de seu sentimento:

Illic si qua meum sepelissent fata dolorem ultimus et posito staret amore lapis, illa meo caros donasset funere crines, molliter et tenera poneret ossa rosa; illa meum extremo clamasset puluere nomen, ut mihi non ullo pondere terra foret.

Se o destino ali (=em Roma) tivesse sepultado meus sofrimentos e a lápide tivesse sido posta sobre meu amor sepulto, ela teria oferecido a meu funeral seus estimados cabelos, e suavemente colocaria meus restos sobre tenras rosas; ela teria, no último momento, clamado meu nome sobre minhas cinzas, a fim de que a terra não me fosse de modo algum pesada.

Perceptível é a presença no texto acima de termos ligados ao ritual fúnebre: sepelire, ultimus lapis, funus, os, rosa, donare crines, puluis, terra. Em seu plano imaginário, o poeta concebe uma Cíntia completamente diferente do que comumente se vê. Ela mais parece uma esposa devotada, a qual lamenta profundamente a perda do ser amado. Assim ele a deseja, e visualiza a morte como única possibilidade de despertar os sentimentos que ela deveria nutrir por ele durante a vida. $\mathrm{O}$ mesmo desejo expressa na elegia 13 do livro II no qual relata a Cíntia como imagina seu funeral: 
Quandocumque igitur nostros mors claudet ocellos, accipe quae serues funeris acta mei. Nec mea tunc longa spatietur imagine pompa nec tuba sit fati uana querela mei; $\quad 20$ Nec mihi tunc fulcro sternatur lectus eburno nec sit in Attalico mors mea nixa toro. Desit odoriferis ordo mihi lancibus, adsint plebei paruae funeris exsequiae.

Sat mea sit magno, si tres sint pompa libelli, quos ego Persephonae maxima dona feram. Tu uero nudum pectus lacerata sequeris nec fueris nomen lassa uocare meum osculaque in gelidis pones suprema labellis, cum dabitur Syrio munere plenus onyx.

Quando quer que a morte, portanto, venha fechar meus olhinhos, ouve os preparativos de minhas exéquias os quais observarás. Nem se prolongue então meu cortejo fúnebre com um longo desfile de imagens ${ }^{11}$, nem a trombeta seja um vão lamento de minha morte; nem se me prepare um esquife com pés de marfim, nem repouse meu cadáver sobre um leito digno de Átalo ${ }^{12}$.Falte-me uma fileira de pratos odoríferos, e que haja um pobre cortejo de um enterro plebeu. Bastante valiosas serão minhas exéquias, se eu tiver por cortejo meus três livrinhos, os quais eu levarei a Perséfone como o maior dos presentes. Tu, porém, Cíntia, seguir-me-ás arranhando o peito nu nem jamais ficarás cansada de chamar por meu nome; e darás os últimos beijos em meus gélidos lábios, quando um vaso de ônix cheio de oferenda síria me for aspergido.

O poeta dá uma ordem a sua amada (accipe), pois em seu imaginário nutre a esperança de que será atendido (serues), de que verá Cíntia em lágrimas com os cabelos desgrenhados, e realizará os ritos conforme os desejos expressos pelo poeta. A aspiração de ver seu amor concretizado leva o poeta a imaginar que diante da morte a amada reconhecerá seu valor e lamentará sua perda como ocorre na elegia 24 do livro II:

11 Nisard (1839, p.557) nos esclarece: "Em Roma, a pompa fúnebre do defunto, segundo seu renome, era acompanhada de um triste e lento cortejo, no qual se levava as imagens dos antepassados paternos e maternos, e onde se misturavam os gemidos aos lúgubres sons dos trompetes e das flautas." // A Rome, la pompe funèbre du défunt, selon son illustration, était accompagnée d'un triste et lent cortège, dans lequel on portait les images des aïeux paternels et maternels, et ou mêlait les gémissements aux sons lugubres des trompettes et des flûtes.

12 Rei de Pérgamo, onde se fabricavam luxuosos leitos com adornos de marfim, era considerado também o inventor da fibra de ouro para fabricar roupas. 
Tu mea compones et dices: "Ossa, Properti, haec tua sunt; eheu! tu mihi certus eras, certus eras eheu! quamuis nec sanguine auito nobilis et quamuis non ita diues eras".

Tu juntarás meus restos e dirás: "São estes teus restos, Propércio; ai de mim! tu me eras fiel, ah! eras fiel, ainda que não fosses nobre pelo sangue de teus antepassados e ainda que não fosses tão rico" -,

e nos versos seguintes:

Hi tibi nos erimus; sed tu potius precor ut me demissis plangas pectora nuda comis.

Eu serei assim para ti; mas antes suplico que sejas tu quem me lamentes com os cabelos em desalinho e o peito nu.

Imagina Cíntia também presente em seu enterro na elegia 16 no livro III, mas na dezenove do livro I descreve suas exéquias sem a presença dela. Sua imaginação, indo além dos limites da vida, perscruta o mundo dos mortos. O sentimento que por ela nutre não é comum, e sua intensidade só pode ser entendida como uma ação de Cupido. Daí transpor os limites da existência terrena, e poder ultrapassar o limiar da morte:.

Non ego nunc tristis uereor, mea Cynthia, Manis nec moror extremo debita fata rogo;

sed ne forte tuo careat mihi funus amore, hic timor est ipsis durior exsequiis.

Agora, minha Cíntia, eu não temo os lúgubres Manes ${ }^{13}$, nem retardo os devidos destinos à última pira. Temo, contudo, que minha morte fique privada de teu amor: este temor é mais penoso que as próprias exéquias.

Pelo primeiro dístico dessa elegia apreendemos que o poeta vive um momento de descrédito completo em relação ao seu envolvimento com Cíntia. Depreende-se que ela o traiu ou o desprezou e, por isso, julga não

13 Conforme a crença popular dos romanos, eram os deuses bons, os espíritos dos mortos, especialmente os dos pais. Eram cultuados com oferendas de vinho, mel e leite e, em seu louvor, celebravam-se as festas chamadas rosaria (ou violaria), nas quais as tumbas eram enfeitadas com rosas (ou com violetas), como também as parentalia, celebradas entre 18 a 21 de fevereiro. 
ter mais motivo para viver. Este poema é quase todo centrado no sofrimento que o envolve por causa da indiferença da mulher amada. Seus pensamentos de morte traduzem, na verdade, o desejo malogrado de vivenciar sua paixão amorosa, e teme não a morte, mas a possibilidade de ela não realizar as devidas exéquias. O sentimento que o abrasa é tão violento que perdurará depois da morte:

Non adeo leuiter noster puer haesit ocellis, ut meus oblito puluis amore uacet.

Nossa Criança não se fixou tão levemente em meus olhinhos, a ponto de minhas cinzas ficarem livres de teu amor por tê-lo esquecido.

Cíntia, sempre surda às súplicas do poeta, leva-o, consciente de que não poderá realizar este amor em vida, a se entregar, em seu imaginário, ao apelo trágico da morte: eis o único plano no qual esta paixão pode se concretizar:

Nunc, quoniam ista tibi placuit sententia, cedam:

tela, precor, pueri, promite acuta magis,

figite certantes atque hanc mihi soluite uitam:

sanguis erit uobis maxima palma meus.

Agora, uma vez que esta decisão te agradou, retirar-me-ei: suplico-vos, Amores, puxai de vossa aljava setas mais aguda traspassai-a em mim competindo e livrai-me desta vida: ser-vos-á meu sangue a maior palma ${ }^{14}$.

Sem qualquer esperança acerca da concretização de seu amor, recorre aos deuses que lhe proporcionaram este "mal", os Amores. Ordena-lhes (promite) o uso de setas agudas para que ele tenha uma morte rápida. Ordena-lhes ainda (figite) que seu peito seja alvo de uma competição (certantes). Ele se dá por vencido ao Amor, e sente-se completamente amarrado aos fortes nós de Vênus e, por isso, vale-se do verbo soluere, cujo primeiro sentido é "desatar os nós", "desprender", i.e., desatar os nós que o prendem a esta vida, e, conseqüentemente à amada. Que disputem para que mais rapidamente ele morra, e ludicamente brinquem com sua vida tal qual brincaram quando lhe proporcionaram esse mal: que sua morte lhe seja tão violenta quão violento

14 Ramo da palmeira dada aos vencedores como símbolo da vitória. 
é seu sofrimento. Suplica ainda aos Amores que apressem este fim inevitável, qualquer que seja o caminho para encontrá-lo -

Nunc iacere e duro corpus iuuat, impia, saxo sumere et in nostras trita uenena manus.

Agora, perversa, a mim apraza lançar-me de um rijo penhasco, e engolir um veneno moído posto em minhas mãos -,

e, numa atitude de desespero, vem-lhe à mente, em um outro poema, a imagem de morrer juntamente com a amada:

Sed non effugies: mecum moriaris oportet;

hoc eodem ferro stillet uterque cruor.

Quamuis ista mihi mors est inhonesta futura:

mors inhonesta quidem, tumoriere tamen.

Mas não escaparás: convém que morras comigo; que por este mesmo ferro escorra gota a gota um e outro sangue. Embora me seja no futuro essa morte vergonhosa - de certo uma morte vergonhosa -: tu contudo morrerás.

Declara-se disposto a "matá-la”, pois, assim talvez, ela possa valorizar seus sentimentos. $\mathrm{O}$ poeta visualiza-se num cenário de tragédia descrito de maneira um tanto mórbida, cheio de termos carregados de apelo trágico. Ele jura fidelidade eterna à amada, por isso não pode conceber sua vida sem a companhia de Cíntia, o que o leva a desejar morrer juntamente com ela:

me tibi ad extremas mansurum, uita, tenebras:

ambos una fides auferet, una dies.

eu hei de te esperar, ó vida minha, até as últimas trevas: um só juramento, um só dia levará nós dois ao mesmo tempo.

Na elegia 16 do livro III, seu amor por Cíntia se mostra tão forte que o leva a desafiar a morte. Tendo recebido uma carta de Cíntia intimando-o a visitá-la altas horas da noite, convence-se de que de nenhum perigo poderá ser vítima (III,16,18): huic generi quouis tempore tuta uia est // "a esta espécie de amante o caminho em qualquer tempo é seguro”. Pelo contrário, o amante "de escasso sangue" deverá inspirar compaixão, e não ódio dos possíveis salteadores noturnos: 
Sanguine tam paruo quis enim spargatur amantis improbus? Exclusis fit comes ipsa Venus.

Quod si certa meos sequerentur funera casus, tali mors pretio uel sit emenda mihi.

Afferet huc unguenta mihi sertisque sepulcrum ornabit custos ad mea busta sedens.

Que facínora, pois, banhar-se-ia do tão escasso sangue ${ }^{15} \mathrm{de}$ um amante? Aos amantes afastados de casa a própria Vênus se faz acompanhante. E se uma fatal desgraça resultasse de minhas desventuras, por tão grande preço eu deveria ainda comprar a morte. Levar-me-á Cíntia aí perfumes e ornará de guirlandas o sepulcro, estando sentada, como guardiã, junto a meu túmulo.

Sente-se protegido pelo Amor, mas, ainda que a morte lhe sobreviesse, poderia transformar o coração da amada e vê-la junto ao seu túmulo. Marca sua poesia com todos os elementos de seu imaginário relacionados à morte: unguentum, serta, sepulcrum, bustum.

A fidelidade do poeta por sua amada firma-se não apenas na vida, mas perdura para além da morte, a qual, em vez de rompê-la, prolonga esta união: ambos una fides auferet, una dies (II,20,18) // "um só juramento, um só dia levará nós dois ao mesmo tempo". Esta ideia é reforçada pelo mito das esposas irrepreensíveis, imortalizadas nos Infernos e que lá prorrogam sua fidelidade sentida em vida:

Andromedeque et Hypermestre sine fraude maritae narrant historiae pectora nota suae:

haec sua maternis queritur liuere catenis bracchia nec meritas frigida saxa manus; narrat Hypermestre magnum ausas esse sorores, in scelus hoc animum non ualuisse suum.

15 Tovar (1963, p 167) é o único comentarista que nos dá uma explicação acerca dessa estranha referência: "O amante, pálido e exangue de desejo, inspira compaixão" // El amante, pálido y exangüe por el deseo, inspira compasión. 
Tanto Andrômeda ${ }^{16}$ quanto Hipermnestra ${ }^{17}$, esposas sem mácula, contam os conhecidos sentimentos de suas histórias: uma lamenta que seus braços estejam machucados por causa das correntes maternas e as suas mãos não tinham merecido os frios rochedos; conta Hipermnestra que suas irmãs ousaram um grande crime, que para esse crime seu coração não teve forças.

Desde o Monobiblos, como faz no poema 19 do livro I- traicit et fati litora magnus amor (v.12) // "um grande amor transpõe até o limiar do destino" -, onde "tenta com exatidão defender a certeza de que o amor pode ultrapassar os limites da morte"18, desenvolve a ideia de que o verdadeiro amor transpõe os limites terrestres. Isso fica evidente diante da iminência da morte ou da separação de algum dos amantes: a amante se faz presente nas exéquias do amado e se reveste de uma inquestionável fidelidade.

Há uma certa obsessão pelo sentimento de fidelidade em Propércio. Em III,12, Póstumo vai à guerra e deixa sua esposa, Élia Gala, em casa. Ao contrário do que um leitor desatento pode pensar, este poema não é um louvor à dedicação de Póstumo às causas do Estado, nem tampouco uma tentativa de consolar sua esposa lembrando-lhe o prestígio do marido e a glória das armas. A elegia inteira converge para um só ponto, indicado no último verso: a fidelidade de Élia Gala: Vincit Penelopes Aelia Galla fidem $(\mathrm{III}, 12,38)$ // "Élia Gala supera a fidelidade de Penélope". Insiste na mesma ideia na carta de Aretusa a Licotas: esposa apaixonada e fiel escreve ao marido ausente, um soldado:

Romanis utinam patuissent castra puellis! essem militiae sarcina fida tuae.

Oxalá os campos militares fossem abertos às mulheres romanas! Eu seria uma fiel bagagem ao teu exército.

16 Cassiopéia, mãe de Andrômeda, muito orgulhosa da própria beleza, queria rivalizar com as Ninfas e até mesmo com Hera. Essas pedem a Poseidon um castigo pela presunção e o deus manda um monstro marinho. O oráculo de Ámon, interrogado pelo rei da Etiópia, Cefeu, predisse que aquele país só estaria livre do monstro se Andrômeda, sua filha, fosse exposta como vítima expiatória. Os etíopes, então, obrigaram o rei a prender a filha a um rochedo. Perseu, voltando de uma expedição contra a Górgona, apaixona-se por ela e promete a Cefeu que a libertaria, caso ele consentisse esta união. Tendo Cefeu aceitado, Perseu mata o monstro e a desposa.

17 Era uma das Danaides, cinqüenta filhas de Dânao, rei de Argos. Com o consentimento de seu pai, casaram-se com seus primos, os quais haveriam de matar por ordem dele, a quem um oráculo havia predito que teria por assassino os genros. Somente Hipermnestra recusou-se a matar seu marido, Linceu, que a respeitaria, mas que, depois, assassinaria o sogro.

18 tries precisely to maintain the belief that love can overcome death (LYNE,1998,p.209). 
Tal qual a Cíntia da elegia 3 do livro I, tal qual Élia Gala, Aretusa é outra Lucrécia, ideal de esposa romana, eternamente fiel a um só homem. Retoma ainda este mesmo tema na elegia 11 do livro IV: elogia Cornélia, que em vida havia sido uma esposa irrepreensível e eternamente fiel ao seu marido Paulo Emílio Lépido. Todos os temas ligados à separação, doença e morte, presentes na última de suas elegias, prestam-se para intensificar ainda mais o sentimento de fidelidade que é confirmado pelo próprio discurso desta dama, a qual dos Infernos fala ao seu marido, consolando-o e assegurando-lhe sua fidelidade em vida:

Nec mea mutata est aetas, sine crimine tota est:

uiximus insignes inter utramque facem.

Mi natura dedit leges a sanguine ductas,

nec possem melior iudicis esse metu.

Quaelibet austeras de me ferat urna tabellas:

turpior assessu non erit ulla meo.

$(\mathrm{IV}, 11,45-50)$

E minha vida não se transformou, permaneceu completamente sem mácula: vivi íntegra entre os dois archotes ${ }^{19}$. Deu-me a natureza leis herdadas pela estirpe, e eu não poderia ser melhor pelo medo de um juiz. Qualquer que seja a urna que tenha de mim um juízo severo, nenhuma mulher, sentada ao meu lado, sentir-se-á mais envergonhada.

Ainda que as atitudes de Cíntia não se comparem às daqueles modelos femininos, o poeta lhe assegura, na elegia 14 do livro II, que jamais deixará de amá-la, que seu sentimento permanecerá inalterável. O poeta, tendo recuperado sua amada, entoa-lhe um verdadeiro canto de triunfo. Cíntia parece ter-se dobrado ante o amor do poeta, o qual, feliz, celebra sua vitória, garantindo-lhe, no final do poema, preferir morrer a lhe ser motivo de desgraça:

Nunc ad te, mea lux, ueniet mea litore nauis seruata, an mediis sidat onusta uadis?

Quod si forte aliqua nobis mutabere culpa, uestibulum iaceam mortuus ante tuum!

Agora para ti, ó minha luz, minha nau chegará a salvo do litoral, ou que encalhe, carregada, em meio ao baixio. E se, por acaso, mudares por alguma culpa minha, que eu jaza morto diante de teu vestíbulo -,

19 Entre o facho nupcial e o funerário. 
por isso jura, num poema em que Cíntia é quem o recrimina e protesta, amor eterno, e afirma que seu coração será somente dela:

De te quodcumque, ad surdas mihi dicitur auris:

tu modo ne dubita de grauitate mea.

Ossa tibi iuro per matris et ossa parentis

(si fallo, cinis heu sit mihi uterque grauis!)

De ti, o que quer que seja, é dito aos meus ouvidos surdos: que tu apenas não duvides de minha constância. Juro a ti pelos ossos de minha mãe e pelos ossos de meu pai (ah! se minto, que ambas as cinzas me sejam funestas!)

Por meio deste juramento o poeta confere a sua relação com Cíntia uma certa atmosfera familiar. Há uma intenção de estabelecer nesta aliança um caráter legal, pois está certo de que este amor é verdadeiro, abençoado. Ainda que este juramento denuncie sua consciência dos limites da vida, ele voltaria, ainda que "morto", contrariando as leis naturais da vida, se por ela fosse chamado:

Solus amans nouit, quando periturus et a qua morte, neque hic Boreae flabra neque arma timet.

Iam licet et Stygia sedeat sub harundine remex cernat et infernae tristia uela ratis, si modo clamantis reuocauerit aura puellae, concessum nulla lege redibit iter.

Só o amante sabe quando e por qual morte há de perecer, e este não teme o sopro do Bóreas nem as armas. Ainda que como remador ${ }^{20}$ esteja sentado entre os caniços do Estige ${ }^{21}$, ele vê a fúnebre vela da barca infernal. Se apenas o sussurro da mulher amada tiver dito que volte, ele voltará pelo caminho por nenhuma lei permitido.

20 A respeito deste remador nos diz Scarcia (1993, p.231): o morto, que segundo a tradição grega, deve colaborar remando com o barqueiro Caronte, toma o remo (diz-se aqui) quando a "barca infernal" ainda se encontra nos baixios da margem // il morto, che secondo la tradizione greca, deve collaborare remando col nocchiero Caronte, prende posto (si dice qui) agli scalmi quando ancora la "barca infernale" poggia mezzo a secco sulla riva.

21 Scarcia (1993, p.231), referindo-se ao Estige, informa-nos ainda: o rio que se encontra na entrada dos Infernos -possui um aspecto de pântano e suas margens são orladas de caniços altos // l'acqua che introduce agli inferi - ha caratteri di palude e le sue sponde sono orlate di alti canneti. 
A fides, na elegia 13 do livro II, projeta-se no âmbito do desejo de que, correspondido, ele possa morrer tranquilo a qualquer hora. Assim, terá a certeza de que ela estará fielmente presente em suas exéquias, prestando-lhe as devidas honras fúnebres. Evoca nesta elegia a morte na expectativa de sensibilizar a amante a com ele se reconciliar:

Non ego sum formae tantum mirator honestae nec si qua illustris femina iactat auos: me iuuet in gremio doctae legisse puellae auribus et puris scripta probasse mea. Haec ubi contigerint, populi confusa ualeto Fabula, nam domina iudice tutus ero. Quae si forte bonas ad pacem uerterit auris, possum inimicitias tunc ego ferre Iouis.

Quandocumque igitur nostros mors claudet ocellos, accipe quae serues funeris acta mei.

Nec mea tunc longa spatietur imagine pompa nec tuba sit fati uana querela mei.

Não sou eu tão admirador de uma beleza nobre nem do fato de uma mulher se vangloriar de seus ilustres antepassados: agradar-me-ia que eu lesse no regaço de uma amante culta e que ela aprovasse, de ouvidos apurados, meus escritos. Quando isso me tiver acontecido, adeus confusa opinião do povo, pois seguro estarei com o juízo de minha amada. E se ela der ouvidos atentos ao meu desejo de paz, poderei eu então suportar as hostilidades de Júpiter. Quando quer que a morte, portanto, venha fechar meus olhinhos, ouve os preparativos de minhas exéquias os quais observarás. Nem se prolongue então meu cortejo fúnebre com um longo desfile de imagens, nem a trombeta seja um vão lamento de minha morte.

A morte para o poeta manifesta-se usualmente como o espaço ou plano no qual este amor pode se efetuar, como uma libertação. Seu temor não é a morte, mas o possível desprezo da amada. Tem consciência de que só a compaixão pode despertar em Cíntia este amor. É patente também o mesmo contraste de ideias entre vida e morte na elegia 19 do livro I na qual expressa a mesma fides no âmbito do desejo, como podemos perceber por meio dos verbos com valor optativo possis, sit, abstrahat, cogat:

Quae tu uiua mea possis sentire fauilla!

Tum mihi non ullo mors sit amara loco; 
quam uereor, ne te contempto, cynthia, busto

abstrahat e nostro puluere iniquus Amor,

cogat et inuitam lacrimas siccare cadentis.

Flectitur assiduis certa puella minis.

Que tu, viva, pudesses sentir isso por minhas cinzas. Então a morte não me seria amarga em nenhum lugar. Como temo, Cíntia, que, uma vez desprezada minha pira, o injusto Amor te afaste de minhas cinzas, e te obrigue, contra tua vontade, a secar as lágrimas que caem: através de constantes ameaças se dobra a amante fiel.

As suas preocupações não estão agora limitadas a sua vida terrena, preocupa-se mais com os ritos fúnebres que lhe são devidos, confiados a Cíntia. Sua existência, sua felicidade está ligada aos sentimentos que ela lhe dedica, essa é a chama que o alimenta. Seguindo a linha de pensamento relativo à morte o poeta aspira pela presença da amada, atitude que possibilita o abrandamento do temor à morte. Teme, contudo, que sua fides possa ser quebrada por influência do iniquus Amor. Quer ele crer que se Cíntia vier, depois de sua morte, a esquecê-lo, a dar a atenção ao outro, não será por sua própria vontade, mas pela ação nefasta do Amor, que pode se fazer presente nos constantes assédios de possíveis pretendentes. Sua fides, por sua vez, perdurará até mesmo nos Infernos, apesar da existência de belas mulheres, nenhuma mulher poderá rivalizar em beleza com a amada, pois a morte não é o fim aos que se unem pela fides:

Illic formosae ueniant chorus heroinae, quas dedit Argiuis Dardana praeda uiris; quarum nulla tua fuerit mihi, Cynthia, forma gratior, et (Tellus hoc ita iusta sinat)

Ali, as belas heroínas, as quais o saque de Dárdano deu aos homens argivos, cheguem em coro: dessas, Cíntia, nenhuma teria para mim uma beleza mais encantadora que a tua, e (assim o permita a justa Terra!).

Na elegia 28 do livro II, contudo, é Cíntia que está na iminência de morrer. Dirigindo-se a Júpiter, o poeta clama e faz promessas por seu restabelecimento, pois de nada lhe adiantaria esta existência sem ela. Os fados parecem implacáveis, e Cíntia está condenada a morrer. Uma cerimônia mágica, contudo, consegue salvá-la desta morte iminente: 
Iuppiter, affectae tandem miserere puellae: tam formosa tuum mortua crimen erit?

[...]

Deficiunt magico torti sub carmine rhombi et iacet exstincto laurus adusta foco;

et iam Luna negat totiens descendere caelo nigraque funestum concinit omen auis.

Vna ratis fati nostros portabit amores caerula ad infernos uelificata lacus.

Sed non unius quaeso, miserere duorum! uiuam, si uiuet; si cadet illa, cadam.

Apieda-te por fim, Júpiter, de minha amada enferma: tão belo cadáver será teu crime?[...] Os rombos ${ }^{22}$ giratórios

22 As opiniões dos comentaristas a respeito desses rombos giratórios divergem um pouco: Scarcia (1993, p. 234) nos diz:

No verdadeiro sentido, ofuso que, quando envolvido pela lã, assume o formato da conhecida figura geométrica; daí, por comparação, o cone (lat. turbo), o pião que gira desenrolando velozmente uma correia que a envolve em espiral. Como as rodas, e outros objetos rotativos, peça essencial de muitos rituais de magia. Aqui os presságios tentados são negativos (o pião pára, o fogo não queima muito as folhas de louro, a lua não participa do rito).

In senso proprio, il fuso con avvolta la lana che assume il profilo della nota figura geometrica; quindi - per comparazione - il "paléo" (lat. turbo), la trottola che si la frullare srotolando velocemente una frusta che l'avvolge a spirale (cfr. 3,6,26). Come le ruote, e altri oggetti rotanti, suppellettile essenziale di molti atti magici. Qui i presagi tentati con la magia sono negativi (la trottola si ferma, il fuoco non arde bene le foglie di alloro, la luna non partecipa al rito).

Nisard (1839,p.560), por sua vez, diz-nos:

O rombo que tira sua etimologia imitativamente de seu barulho, do verbo grego r(ombein (volvere), era, segundo uns, um pião ou carrapeta, que girava com a ajuda de uma tira de couro; segundo outros, era uma veloz máquina à roda. Os rombos só eram usados em cerimônias de magia [...] ; ele forçava a lua a descer sobre a terra. Quanto ao loureiro, se as folhas desta árvore vaticinadora não crepitavam nas chamas, tirava-se disto um péssimo presságio.

Le rhombe, qui tire son étymologie très-imitative de son bruit, du verbe grec $r$ (ombein (volvere), était, sélon les uns, un sabot, ou toupie, tournant à l'aide de lanières, ou bandelettes; selon les autres, céait un rouet rapide. Le rhombe nétait d'usage que dans les cérémonies magiques [...]; il forçait la lune à descendre sur la terre. Quant au laurier, si les feuilles de cet arbre fatidique ne pétillaient pas dans les flammes, on en tirait un très-mauvais présage.

Tovar (1963,p.105), por outro lado, explica-nos acrescentando uma outra ideia a esse instrumento:

O rombo era um elemento da magia grega e romana. Eram peças de madeira com uma corda num extremo através da qual as mesmas giravam produzindo um zumbido. Era usado como sortilégio pelas magas ou pelos que estavam apaixonados. Acreditavam que girando o rombo e pronunciando palavras mágicas, fariam vir o homem amado.

El rombo era un elemento de la magia griega y romana. Eran piezas de madera con una cuerda en un extremo con la que se les hacía girar produciendo un zumbido. Era usado 
cessam sob a palavra mágica e jaz queimado o loureiro com o fogo apagado; tanto a lua já muitas vezes se recusa a descer do céu, como o negro pássaro ${ }^{23}$ anuncia o funesto presságio. Uma só barca do destino, azul-escura, navegando os lagos dos Infernos, levará nossos amores. Compadece-te dos dois, suplico-te, não, porém, de um só! viverei, se ela viver; se ela morrer, eu morrerei.

A morte de Cíntia não pode ser aceita pelo poeta, pois sem a amada ele não sobreviverá. Sente-se completamente dependente, pois nutre a certeza de tê-la no futuro ao seu lado, e, por isso, pede pelos dois. A morte da amante determina consequentemente a "morte" do amor que mantém vivo o poeta, daí a simbologia da barca que leva aos Infernos nostros amores. Manifesta assim na relação com Cíntia um sentimento baseado na fides, capaz de se manter inalterável, ainda que esta chegue à velhice:

quamuis te longae remorentur fata senectae, cara tamen lacrimis ossa futura meis.

Ainda que os fados te reservem uma longa velhice, teus ossos, contudo, hão de ser caros às minhas lágrimas.

O mesmo juramento é feito, numa outra elegia, a 24 do livro II, na qual lhe certifica de que ele - ao contrário do seu rival no amor por Cíntia - não deixará de estar ao seu lado, de lhe ser fiel, nem na velhice ou no além-túmulo -

At me non aetas mutabit tota Sibyllae, non labor Alcidae, non niger ille dies.

Tu mea compones et dices: "Ossa, Properti, haec tua sunt? eheu! tu mihi certus eras."

Quanto a mim, não me fará mudar nem a vida inteira da Sibila, nem os trabalhos de Alcides, nem aquele dia fatal. Tu juntarás meus restos e dirás: "São estes teus restos, Propércio; ai de mim! tu me eras fiel.”-,

pois, ela, como afirma na elegia 3 do livro II, junta à sua beleza, semelhante à de Helena, seus dotes na dança, na música e no verso. Que ele

como sortilegio por las magas o las enamoradas. Creían que girando el rombo y pronunciando palabras mágicas, harían venir al hombre amado.

23 Paganelli (1929,p.74) afirma ser "o mocho, pássaro da noite e de mau augúrio" // le hibou, oiseau de nuit et de mauvais augure. 
então permaneça sob seu império e que a morte o leve se não cumprir o juramento:

His saltem ut tenear iam finibus!aut mihi,si quis, acrius ut moriar, uenerit alter amor!

Que eu então fique ao menos preso nestes limites! ou que eu morra mais violentamente, se algum outro amor me sobrevier!

O poeta busca incessantemente reciprocidade no sentimento que dedica à amada, no entanto, parece ver esgotadas as possibilidade de concretização desse amor, razão de seu viver. A fides pode ser considerada um dos fundamentos do amor em Propércio e o leit-motiv de sua poesia. A presença da amante nos funerais do poeta manifesta, de certo modo, uma ligação tão profunda e eterna que nem mesmo a morte poderia quebrar.

Por fim, o poeta, sem esperanças de que ela desperte para esta paixão, busca a morte como única forma de atrair sua compaixão. A morte se afigura como última tentativa do poeta de despertar a afeição de sua amada, apresenta-se como solução final do seu sofrimento em vida. Desiludido, quer crer não haver mais razão para temer a morte, nem tampouco criar expectativa de uma vida longa. Morrer é o que visualiza como única saída para seu sofrimento na tentativa de que ao menos depois de morto ela o veja com outros olhos, que pelo menos ela possa sentir por ele o que não sentiu em vida: a falta da fides - isso sim - seria mais doloroso que seu próprio funeral.

\section{BIBLIOGRAFIA}

CICERO. Tusculanae Disputationes. Tome I. $4^{\mathrm{e}}$. éd. Texte établi et traduit par G. Fohlen et J. Humbert. Paris: Les Belles Lettres, 1970.

HORACE. Odes et Epodes. Texte établi et traduit par F. Villeneuve. Paris: Les Belles Lettres, 1990.

LÍRICOS GRIECOS: elegiacos e yambógrafos arcaicos (siglos VII-V a.C.). Texto traducido por Francisco R. Adrados, 'Mimnermus', pp.207-225. LYNE, Richard O. A. M. Love and death: Laodamia and Protesilaus in Catullus, Propertius, and others. The Classical Quarterly, Oxford, vol. XLVIII, n. 1, pp. 200-212, 1998. 
NISARD. "Notes sur Properce”. In: Collection des Auteurs Latins. Publiée sous la direction de M. Nisard. Paris: J.-J. Dubochet et compagnie, 1839. OVIDE. Héroïdes. Texte établi par H. Bornecque et traduit par M. Prévost. Paris: Les Belles Lettres, 1989.

PAGANELLI, D. “Introduction". In: PROPERCE. Élégies. Paris: Les Belles Lettres, 1929.

PROPERCE. “Elegies”. In: Collection des AUTEURS LATINS. Publiée sous la direction de M. Nisard. Paris: J.-J. Dubochet et compagnie, 1839. PROPERCIO. Elegías. Edición, tradución, introdución y notas de António Tovar e María T. Belfiore Mártire. Barcelona: Ediciones Alma Mater, 1963.

PROPERZIO, Sesto. Elegie. 2. ed. Traduzione di Luca Canali.

Introduzione di Paolo Fedeli. Commento di Riccardo Scarcia. Milano:

Biblioteca Universale Rizzoli, 1993.

SCARCIA, Riccardo. “Commento". In: PROPERZIO. Elegie. 2. ed.

Milano: Biblioteca Universale Rizzoli, 1993.

TOVAR, Antonio. “Notas”. In: PROPERCIO. Elegías. Edición, tradución, introdución y notas de António Tovar e María T. Belfiore Mártire. Barcelona: Ediciones Alma Mater,1963.

Recebido em: 01/10/2015. Aceito em: 30/10/2015. 